\title{
P03-015 - Dapson treats chronic Pupura Schoenlein (PSH)
}

\author{
G Dueckers $^{{ }^{*}}$, M Frosch ${ }^{2}$, C Assaf ${ }^{3}$, H Wiggermann $^{4}$, D Schneider $^{5}$, T Niehues $^{1}$ \\ From 7th Congress of International Society of Systemic Auto-Inflammatory Diseases (ISSAID) \\ Lausanne, Switerland. 22-26 May 2013
}

\section{Introduction}

PSH is common and, with few exceptions, resolves spontaneously. In complicated cases treatment can be difficult.

\section{Case Report}

Here we present an 11 year old Iranian girl, of healthy parents suffered from chronic PSH with chronic exanthema, severe ulcerative dermatitis and arthralgia. Clinical observation: no fever, no arthritis, no signs of polyserositis or hepatosplenomegaly; Laboratory: normal values (full blood count, CRP, complement (C3, C4), no autoantibodies (ANA, ANCA, anti-ds-DNA), no cryoglobulins, zinc, IgG, IgM). Abnormal findings: highly elevated IgA in serum (maximum $2030 \mathrm{mg} / \mathrm{dl}$ ), elevation of ESR and MRP8/ 14. Skin biopsy: leukocytoclastic infiltrates in subcutaneous fatty tissue. Immunohistochemistry: IgA deposits in tip of papillae and upper corium. No mutation in Marenostrin was found. Multimodal therapeutic approaches (Cortisone, Methotrexate, Azathioprine, Colchicine, i.v. Immunoglobulins) remained without success for 8 years. With the administration of Dapsone symptoms resolved within days and remain under control for $>8$ months now. Met-Hb level is tolerable.

\section{Discussion}

Anti-inflammatory potency of dapsone is illustrated. Therapeutic efficacy of Dapsone has been reported in chronic PSH[1,2], but the mechanism remains to be fully elucidated. Hypothesis: Endothelial cells and hyperreactive B-cells (as illustrated by IgA elevation) secrete IL-8. IL-8 is elevated in patients with PSH [3]. IL-8 stimulates perivascular invasion by neutrophils. Dapsone can inhibit secretion of IL-8 [4], thereby impairing neutrophil function [5-7].

${ }^{1}$ Childrens Hospital, Helios Kliniken, Krefeld, Germany

Full list of author information is available at the end of the article
In conclusion Dapsone might be benefical for complicated cases of PSH. The mechanism of its antiinflammatory potency remains to be elucidated.

\section{Competing interests \\ None Declared.}

\section{Authors' details}

${ }^{1}$ Childrens Hospital, Helios Kliniken, Krefeld, Germany. ${ }^{2}$ Pediatrics, Vestische Kinderklinik, Datteln, Germany. ${ }^{3}$ Dept. Dermatology, Helios Klinken, Krefeld, Germany. ${ }^{4}$ Pediatrics, Private Practice, Schwerte, Germany. ${ }^{5}$ Childrens Hospital, Kliniken Dortmund GmbH, Dortmund, Germany.

Published: 8 November 2013

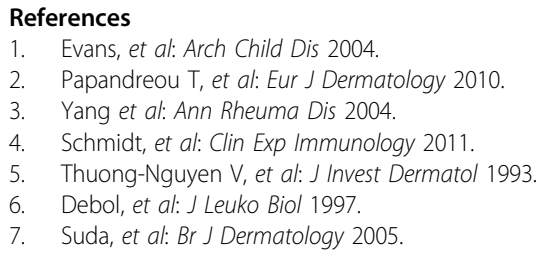

doi:10.1186/1546-0096-11-S1-A213

Cite this article as: Dueckers et al.: P03-015 - Dapson treats chronic Pupura Schoenlein (PSH). Pediatric Rheumatology 2013 11(Suppl 1):A213.

Submit your next manuscript to BioMed Central and take full advantage of:

- Convenient online submission

- Thorough peer review

- No space constraints or color figure charges

- Immediate publication on acceptance

- Inclusion in PubMed, CAS, Scopus and Google Scholar

- Research which is freely available for redistribution

\section{Biomed Central}

(c) 2013 Dueckers et al; licensee BioMed Central Ltd. This is an Open Access article distributed under the terms of the Creative Commons Attribution License (http://creativecommons.org/licenses/by/2.0), which permits unrestricted use, distribution, and reproduction in any medium, provided the original work is properly cited. 